\title{
POTENSI BAHAN BANGUNAN DI PULAU NIAS UNTUK MENUNJANG PEMBANGUNAN PASCA GEMPA DAN TSUNAMI
}

\author{
Oleh : \\ Ganjar Labaik \\ Kelompok Program Penelitian Mineral
}

\section{SARI}

Sumber daya alam Pulau Nias pasca gempa dan tsunami belum ditambang untuk keperluan kesejahtraan masyarakat. Dengan tidak adanya cukup data atau tidak memadainya data dari sumber daya alam maka pemerintah daerah belum tertarik untuk memanfaatkannya secara optimal.

Berdasarkan hasil penyelidikan Pusat Sumber Daya Geologi bahwa potensi sumber daya alam terdiri atas batugamping, batupasir, pasir dan kerikil dimana daripadanya diperlukan bahan bangunan untuk rehabilitasi dan renovasi infrastruktur pulau tersebut. Apabila berhasil dikelola dapat menciptakan pemulihan kondisi sosial-ekonomi dan yang paling penting meningkatkan pendapatan daerah otonomi.

\section{ABSTRACT}

Natural resources of Nias Island remained post-disaster of earthquake and tsunami have not been exploited yet for public prosperity. On the other hand there are neither sufficient nor representative data of those resources though the local government seems to be uninterested yet to utilize optimally the resources.

Based on investigation result of.Center for Geological Resources that those potential resources consist of limestone, sandstone, sand and gravel deposits; from which building materials are needed for rehabilitation and renovation of the islands infrastructures. If utilization of resources is managed succesfully, it enable to create recovery of social-economic condition and most importantly to increase autonomical income.

\section{PENDAHULUAN}

\subsection{Latar Belakang}

Bencana alam akhir-akhir ini terjadi secara beruntun di P. Nias dan sekitarnya, dimulai dari gempa bumi yang kemudian memicu gelombangtsunami telah mendapat banyak sorotan dari segenap lapisan masyarakat dunia. Tidak saja dalam konteks keprihatinan atas penderitaan yang dialami oleh masyarakat yang mengalaminya langsung akibat dari bencana tersebut, tetapi juga ada upaya untuk merehabilatasi dan mengembalikan sekaligus membangun kembali jaringan infrastruktur yang hancur akibat bencana tersebut.

Kekayaan alam yang terdapat di P. Nias selama ini belum banyak tersentuh apalagi dimanfaatkan secara optimal untuk meningkatkan taraf hidup masyarakat. Perhatian pemerintah untuk memanfaatkannya sebagai sumber pertumbuhan ekonomi masih dibilang relatif kecil.

Dari berbagai pendapat yang berkaitan dengan hal tersebut yang selama ini berkembang salah satu faktornya adalah kurangnya mendapat perhatian dari berbagai pihak untuk mengembangkan potensi yang ada.
Pendapat tersebut antara lain menunjukkan bahwa P. INias dan pulau-pulau sekitarnya merupakan kawasan yang rentan terhadap bencana alam, kawasan yang terisolasi dan terbelakang, serta rawan terhadap gangguan keamanan.

Padahal pengembangan kawasan P. Nias akan mendatangkan manfaat antara lain : secara ekonomi, potensi sumberdaya alam cukup besar sehingga jika pulau tersebut berhasil dikembangkan secara optimal, maka akan menjadi sumber Pendapatan Asli Daerah, dan secara sosial pengembangan kawasan tersebut akan dapat mengurangi dampak kesenjangan pembangunan antar wilayah.

\subsection{Maksud danTujuan}

Kekayaan alam yang terkandung di P. Nias belum banyak dimanfaatkan secara optimum untuk meningkatkan kesejahteraan masyarakat setempat. Perhatian pemerintah untuk memanfaatkan kekayaan alamnya sebagai sumber pertumbuhan ekonomi masih dibilang relatif kecil.

Tulisan ini diharapkan dapat memberikan informasi mengenai potensi bahan bangunan yang terdapat di P. Nias yang dapat dimanfaatkan untuk membangun kembali infrastruktur yang porak poranda akibat bencana alam berupa gempa bumi dan tsunami pada akhir tahun 2004 
yang lalu, sehingga pada gilirannya dapat meningkatan tarap hidup masyarakat. Selain itu dengan informasi tersebut diharapkan dapat mendorong peran aktif pihak swasta ataupun investor lainnya untuk menanamkan investasi di P. Nias pada bidang usaha tertentu yang dapat menguntungkan semua pihak.

\subsection{Lokasi Daerah Penyelidikan}

Pulau Nias dan kepulauan sekitarnya secara administratif termasuk kedalam wilayah Provinsi Sumatera Utara. Pulau ini terbagi menjadi dua Kabupaten, yaitu Kab. Nias dan Kab. Nias Selatan.

Secara geografis daerah penyelidikan dibatasi oleh koordinat sebagai berikut : Kabupaten Nias, berada pada koordinat diantara : 97055'30" -98042'30" Bujur Timur dan 2050'30" - 3018'30" Lintang Utara, serta Kabupaten Nias Selatan berada diantara koordinat : 98035'30" BT 99039'30" Bujur Timur dan 2O37'30" - 3O19'30" Lintang Utara (gambar 1).
Dengan luas areal mencapai $\pm 5.625 \mathrm{~km} 2$, Kepulauan Nias terdiri dari 132 pulau besar dan pulau kecil, dimana pulau yang berpenghuni sebanyak 33 buah dan yang tidak 99 buah, dengan jumlah penduduk yang menetap di P. Nias sebanyak 678.347 jiwa. Data tahun 2004 menunjukkan $56,99 \%$ penduduk Nias masih tergolong miskin. Hal ini menunjukan bahwa P. Nias sangat terisolir dan kurangnya mendapat perhatian dari pemerintah.

\section{PEMBAHASAN}

\subsection{Geologi Daerah Penyelidikan}

\subsubsection{Morfologi}

Berdasarkan kenampakan bentang alam dan peta topografi daerah Pulau Nias dan sekitarnya, morfologi daerah penyelidikan terbagi menjadi 2 bagian, yaitu satuan morfologi dataran rendah bergelombang dan satuan morfologi perbukitan.

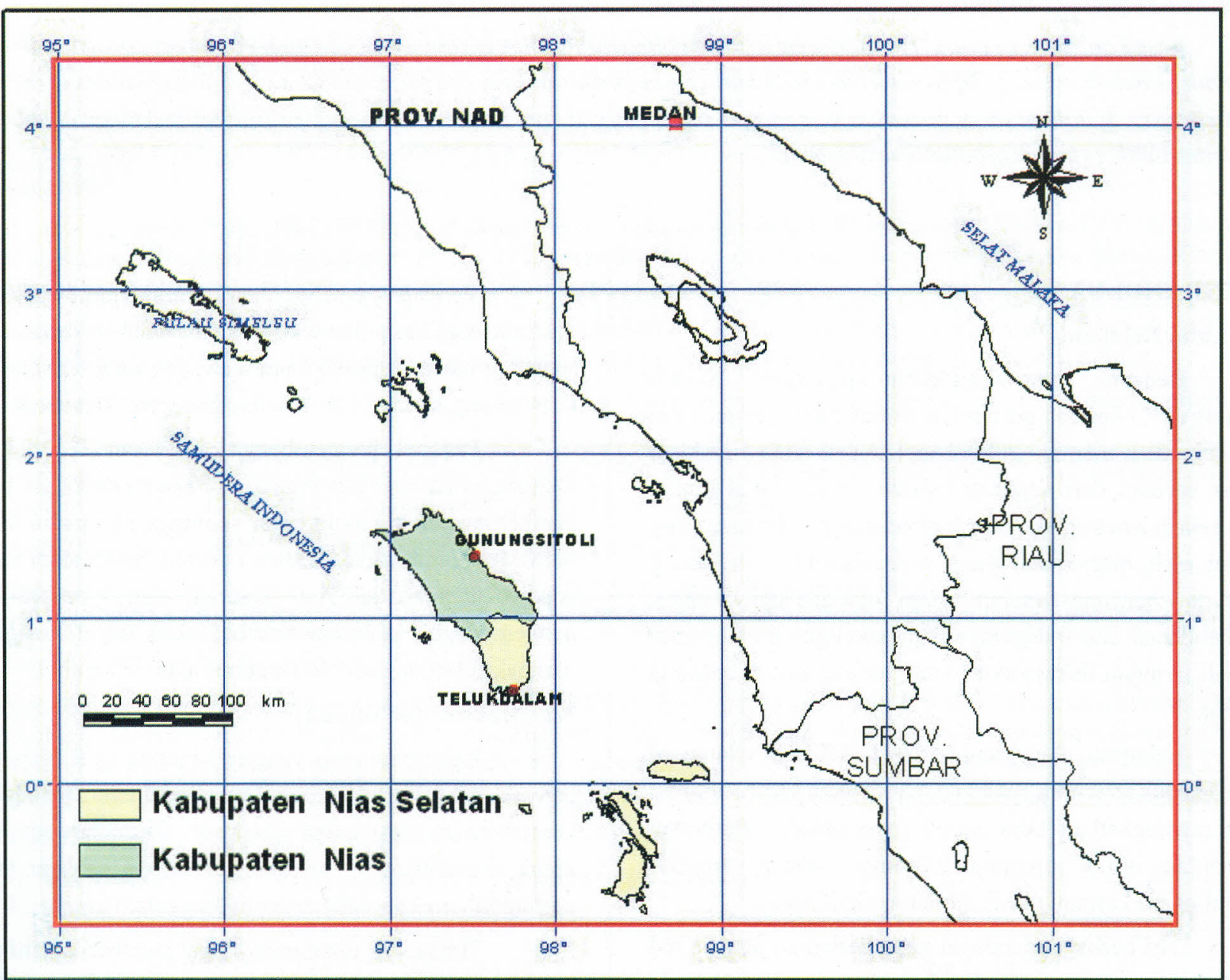

Gambar 1. Lokasi Penyelidikan Bahan Bangunan di Kab. Nias dan Nias Selatan, Provinsi Sumatera Utara 


\section{Morfologi Dataran Rendah Bergelombang}

Satuan morfologi ini terdapat di sebelah utara dan barat daya daerah penyelidikan dan menempati hampir $45 \%$ dari luas areal P. Nias, dengan ketinggian dari 45 - 100 meter dari permukaan laut. Batuan penyusunnya terdiri dari lempung, napal dan batu pasir serta endapan aluvium.

Lokasi satuan morfologi dataran rendah bergelombang ini terutama mencakup beberapa daerah, diantaranya: daerah Sitoluari, Lahewa, Lotu, Lahusa, Orahili, dan Hilimbowo.

\section{Morfologi Perbukitan}

Satuan ini menempati sebelah selatan dan tenggara wilayah penyelidikan, menempati hampir $55 \%$ dari luas areal P. Nias dengan ketinggian 75-800 meter dari permukaan laut. Morfologinya membentuk bukit-bukit yang memanjang, sedangkan batuan penyusun dari satuan morfologi ini umumnya adalah batugamping dan batupasir graywacke dari Komplek Bancuh.

\subsubsection{Stratigrafi}

Satuan stratigrafi daerah penyelidikan berdasarkan
Peta Geologi Lembar Nias, (Djamal, B. dkk, 1994) dan Lembar Telo, (Nas, D.S. dan Supandjono, J.B. 1995), skala 1 : 250.000, PPPG Bandung, (Gambar 2). tersusun oleh formasi batuan yang berurutan dari muda ke tua sebagai berikut.

\section{Aluvium (Qa) :}

Satuan ini berupa endapan sungai, rawa dan pantai yang terdiri dari bongkahan batugamping, lempung, lanau, pasir lepas, kerikil, lumpur dan sisipan gambut yang ditemukan juga di muara sungai. Satuan yang masih aktif proses pengendapan nya ini berumur Kuarter.

\section{Formasi Gunungsitoli (Qtg):}

Batuan penyusun Formasi Gunungsitoli terdiri dari batugamping terumbu, batugamping lanauan, batupasir gampingan, batupasir kuarsa halus gampingan, napal dan batulempung pasiran. Belapis baik dan terlipat lemah. Formasi ini berumur Plio-Plistosen, terendapkan di wilayah laut dangkal. Formasi ini menutupi tak selaras Formasi Gomo dan Formasi Lelematua. Tebal formasi ini diduga sekitar $120 \mathrm{~m}$.

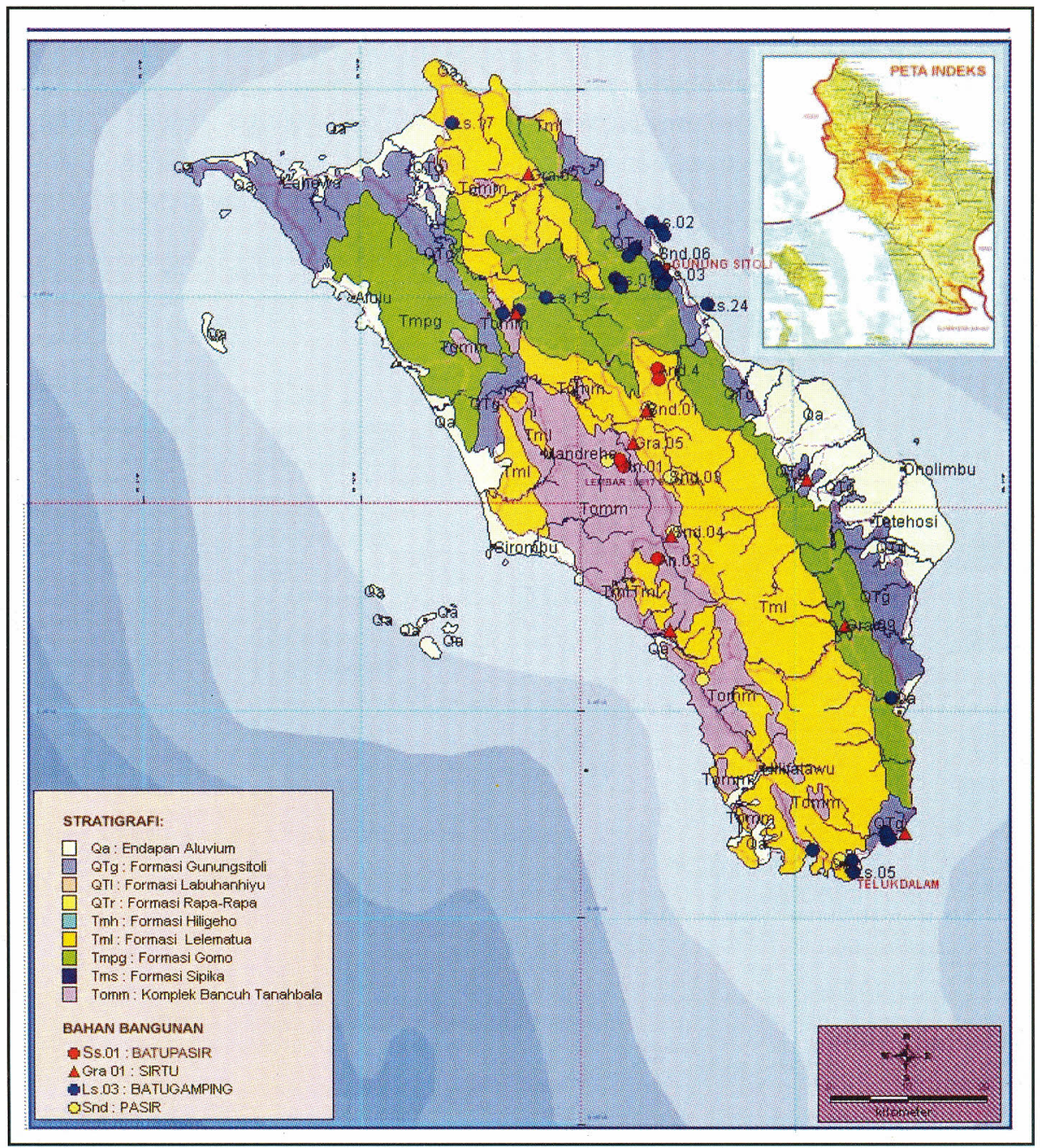

Gambar 2. Peta Geologi dan Lokasi Keterdapatan Bahan Bangunan di P. Nias, Prov. Sumatera Utara 


\section{Formasi Gomo (Tmpg) :}

Batuan penyusun Formasi Gomo terdiri dari batulempung, napal, batupasir dan batugamping, bersisipan napal tufan, tuf dan gambut, berlapis baik dan terlipat kuat. Umumnya berstruktur sedimen pelapisan sejajar/paralel lamination. Ditemukan juga fosil foraminifera, plankton dan foraminifera bentonis yang diendapkan pada lingkungan sub Litoral-Batial, berumur Miosen Tengah-Pliosen. Tebal formasi ini berkisar antara 1.250 meter dan 2.500 meter.

\section{Formasi Lelematua (Tml) :}

Batuan penyusun Formasi Lelematua terdiri dari perselingan batupasir, batulempung, dan batulanau, konglomerat dan tuf; bersisipan tipis batubara dan serpih; berlapis baik dan terlipat kuat. Umumnya berstruktur sedimen pelapisan sejajar. Formasi ini diendapkan dalam lingkungan sub litoral-neritik luar. Formasi ini menutupi tak selaras komplek Bancuh. Tebal formasi ini diduga sekitar $2.000 \mathrm{~m}$. Umurnya Miosen awal-Miosen akhir.

\section{Komplek Bancuh (Tomm) :}

Komplek Bancuh merupakan batuan tertua di daerah penyelidikan, terdiri dari bongkahan berbagai jenis dan ukuran batuan. Batuan penyusunnya terdiri dari peridotit, gabro terserpentinkan, serpentinit, basal, sekis, serpih, konglomerat, breksi, batugamping, betupasir, dan rijang. Banyak dijumpai urat-urat kalsit dan kuarsa. Kompleks ini bersentuhan secara tektonik dengan Formasi Lelematua yang berumur Miosen Awal Miosen Akhir.
Berdasarkan posisi stratigrafinya, ditafsirkan terbentuk pada Oligosen awal Miosen Awal.

\section{Komplek Bancuh (Tomm) :}

Komplek Bancuh merupakan batuan tertua di daerah penyelidikan, terdiri dari bongkahan berbagai jenis dan ukuran batuan. Batuan penyusunnya terdiri dari peridotit, gabro terserpentinkan, serpentinit, basal, sekis, serpih, konglomerat, breksi, batugamping, betupasir, dan rijang. Banyak dijumpai urat-urat kalsit dan kuarsa. Kompleks ini bersentuhan secara tektonik dengan Formasi Lelematua yang berumur Miosen Awal Miosen Akhir. Berdasarkan posisi stratigrafinya, ditafsirkan terbentuk pada Oligosen awal Miosen Awal.

\subsection{Bahan Galian}

Setelah kejadian bencana alam berupa gempa bumi dan tsunami di P. Nias, upaya penanganannya yang harus segera dilakukan adalah tindakan tanggap darurat, rehabilitasi, rekonstruksi, pencegahan, mitigasi dan kesiap siagaan.

Untuk proses rehabilitasi dan rekontruksi, terutama untuk fasilitas pembangunan fisik (Gambar 3) akibat bencana alam tersebut, perlu adanya ketersediaan bahan bangunan yang memadai. Berdasarkan hasil penyelidikan yang telah dilakukan Pusat Sumber Daya Geologi, daerah ini memiliki beberapa bahan galian bangunan yang bisa menopang kegiatan tersebut diantaranya ; batugamping, batupasir, pasir dan sirtu (Martua Raja, dkk., 2006).

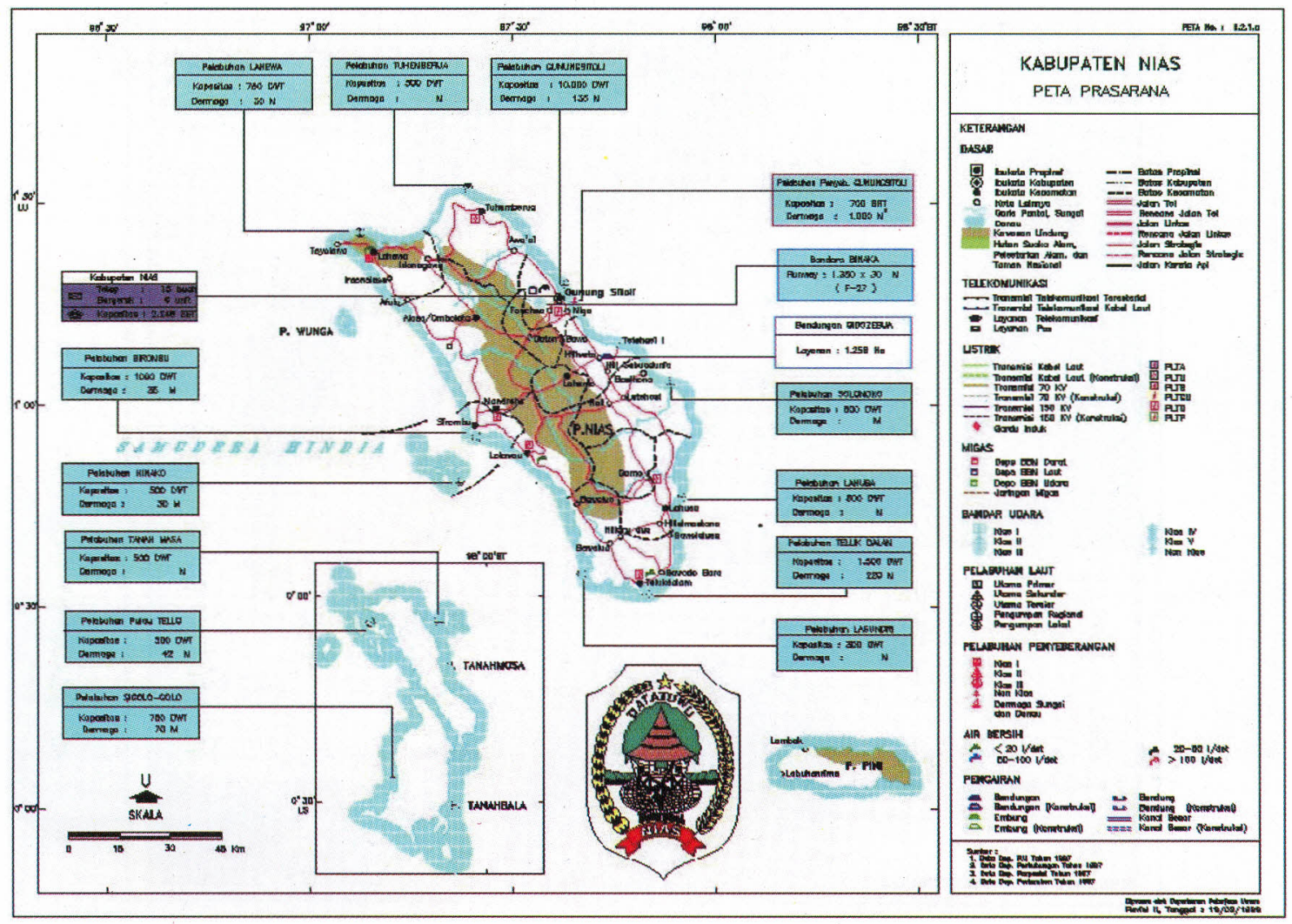

Gambar 3 Peta Prasarana Kab. Nias dan Nias Selatan yang perlu mendapat perhatian pembangunan paska bencana alam. 


\section{Batugamping}

Batugamping merupakan batuan sedimen karbonat yang terdapat di P. Nias sebarannya cukup luas. Secara megaskopis, bahan tambang batugamping ini berwarna putih, putih kekuningan, abu-abu hingga kuning kehitaman.

Berdasarkan determinasi bahan tambang, batugamping ini merupakan salah satu bahan galian industri yang sangat banyak kegunaannya, diantaranya bisa dipakai untuk bahan bangunan.

Analisa petrografi menunjukkan batugamping bioklastik, berstruktur oolitik, berbutir sangat halus hingga $0,10 \mathrm{~mm}$, tersusun oleh $90 \%$ karbonat dan $10 \%$ kalsit. Berdasarkan analisa kimia mengandung 49,4554\% CaO; 0,362,09\% MgO dan 0,201,31\% Fe2O3 + Al2O3.

Lokasi batugamping ini sebagian besar berada disepanjang jalan di pantai Timar Pulau Nias, bagian Utara daerah penyelidikan yaitu di Kecamatan Lahewa dan sekitarnya, Kecamatan Alasa, Kecamatan Gunungsitoli, Kecamatan Hiliduho, dan dibagian Selatan daerah penyelidikan yaitu Kecamatan Teluk Dalam.

Umumnya batugamping di daerah penyelidikan adalah batugamping terumbu dari Formasi Gunungsitoli, berwarna putih-kuning, kecoklatan, pejal dan keras. Di Kecamatan Hiliduho dan Kecamatan Teluk Dalam terdapat sebagian batugamping yang sudah terubah menjadi batugamping kristalin.

Sebagian besar batugamping sudah ditambang masyarakat untuk dipakai sebagai bahan bangunan seperti : pondasi jalan, split, batubelah untuk bangunan dan jembatan (Foto 1)..

Lokasi endapan batugamping ini pada umumnya merupakan daerah perbukitan yang berelief curam dan terjal dan dibeberapa tempat memperlihatkan perbukitan memanjang dengan morfologi bergelombang.

Potensi endapan batugamping Kabupaten Nias mempunyai luas sebaran 750 ha dengan jumlah sumber daya tereka 572.000 .000 ton dan Kabupaten Nias Selatan mempunyai luas sebaran 350 ha dengan jumlah sumber daya tereka 299.000.000 ton.

Pasir

Bahan galian bangunan ini dijumpai di Desa Hiliuse, Kec. Lelepitumoi, Desa Lelejirugi, Kec. Mandrehe, Desa Hilibadolu, Kec. Lolowau, Desa Balelowutani dan Desa Teluk Dalam, Kec. Teluk Dalam dan Desa Tumori, Kec. Gunungsitoli, umumnya berwarna kuning-kecoklatan, abuabu kehitaman, berbutir halus sampai kasar, dan mudah diremas.

Petrografi batuan ini memperlihatkan tekstur klastik berbutir halus hingga $0,20 \mathrm{~mm}$, bentuk butir membundar tanggung - menyudut tanggung, kemas terbuka, terpilah sedang, tersusun oleh butiran kuarsa, felspar, mineral opak, yang tersemenkan oleh muskovit, biotit dan klorit

Pasir yang terdapat di P. Nias sebagian besar sudah ditambang oleh penduduk setempat dan dipakai sebagai bahan bangunan, baik secara manual menggunakan skup dan cangkul maupun memakai alat-alat berat memakai escavator. Selain untuk dipakai sendiri untuk membangun atau memperbaiki rumahnya yang rusak akibat bencana alam, batuan ini juga dijual kepada umum oleh pengusaha penambang pasir (Foto 2).

\section{Batupasir}

Batupasir yang dijumpai dilapangan berupa batupasir metasedimen yang sangat keras, ditemukan di Desa Lelegohi dan Desa Tuhemberua, Kec. Mandrehe, Desa Tesigoro, Kec. Lolowau, Desa Puloloai, Kec. Hilisrangkai dan Desa Lelepose, Kec. Hiliduho, umumnya berwarna abuabu, kehitaman, keras dan kompak (foto 3).

Dibawah mikroskop batuan ini adalah batupasir graywacke, bertekstur klastik, berbutir halus hingga 0,15$0,20 \mathrm{~mm}$, bentuk butir membundar tanggung-menyudut tanggung, kemas terbuka, terpilah sedang. Batuan tersebut tersusun oleh butiran kuarsa : $52-75 \%$, felspar : $5 \%$, mineral opak : $5 \%$, klorit : $8 \%$, serisit : $20 \%$, muskopit : $5 \%$, kalsit $10 \%$ dan mineral kriptokristalin : $5-10 \%$

Lokasi batupasir pada umumnya merupakan daerah perbukitan seperti yang terlihat di Kecamatan Mandrehe di mana batupasir di Desa Lelegohi dan Desa Tuhemberua merupakan satu perbukitan, yaitu Bukit Somomo, di lokasi ini batupasir sebagian sudah digali oleh penduduk setempat dipakai untuk pondasi. Di Desa Puloloi dan Desa Lelepose, batupasir sudah ditutupi oleh tanah penutup yang cukup tebal.

Berdasarkan hasil analisa fisik di Laboratorium, batupasir ini memiliki kuat tekan 804,79 $861,63 \mathrm{~kg} / \mathrm{cm} 2$. Dengan demikian batuan ini bisa dimanfaatkan untuk konstruksi ringan. Potensi endapan batupasir Kabupaten Nias mempunyai luas sebaran 500 ha dengan jumlah sumber daya tereka 448.000 .000 ton.

\section{Sirtu}

Sirtu merupakan bahan galian hasil rombakan yang telah mengalami transportasi dan diendapan disungai yang terdiri dari pasir, kerikil dan batu berbagai jenis dan ukuran diantaranya adalah batuan basal dan serpentinit.

Di daerah penyelidikan bahan galian sirtu tersebut terdapat di 10 lokasi yang tersebar di kelokan sungai atau didataran aluvial. Di beberapa lokasi endapan sirtu ini sudah ditambang dengan menggunakan alat berat, dipakai untuk bahan bangunan dan pengeras jalan. Di beberapa lokasi yang dijumpai, penduduk setempat mengumpulkan bongkahan 
batuan dari hasil endapan sungai ini untuk dijadikan split dan dipakai untuk keperluan pengerasan jalan, jembatan dan pondasibangunan.

Berdasarkan hasil perhitungan ketebalan sirtu, lebar dan panjang sungai tempat lokasi sirtu berdasarkan titik lokasi pengamatan dilapangan, luas sebarannya \pm 25 ha dengan jumlah sumber daya tereka 1.000 .000 ton.

\section{DISKUSI}

Setelah diguncang bencana alam berupa gempa bumi dan datangnya gelombang tsunami yang telah menghancurkan infra struktur di P. Nias dan sekitarnya, perlu segera dilakukan proses rehabilitasi dan rekontruksi, terutama masalah yang menyangkut fasilitas pembangunan fisik (Foto 4).

Dari hasil penyelidikan yang telah dilakukan, daerah ini memiliki beberapa bahan galian bangunan yang cukup potensial dan bisa dimanfaatkan untuk menopang kegiatan tersebut, diantaranya adalah; batugamping, batupasir, pasir dan sirtu.

Pemanfaatan bahan bangunan tersebut bisa untuk membangun rumah, pertokoan, perkantoran, jalan, jembatan dan fasilitas lainnya. Namun yang perlu diperhatikan adalah saat perencanaannya pembangunan fasilitas tersebut, mengingat P. Nias merupakan kepulauan busur dalam (inner island arc) yang berada pada jalur tumbukan dua lempeng di bagian sisi sebelah barat Sumatera yang terus bergerak/geser ke arah kanan (dextral strike slip fault) yang merupakan daerah rawan terhadap bencana alam (gambar 4).

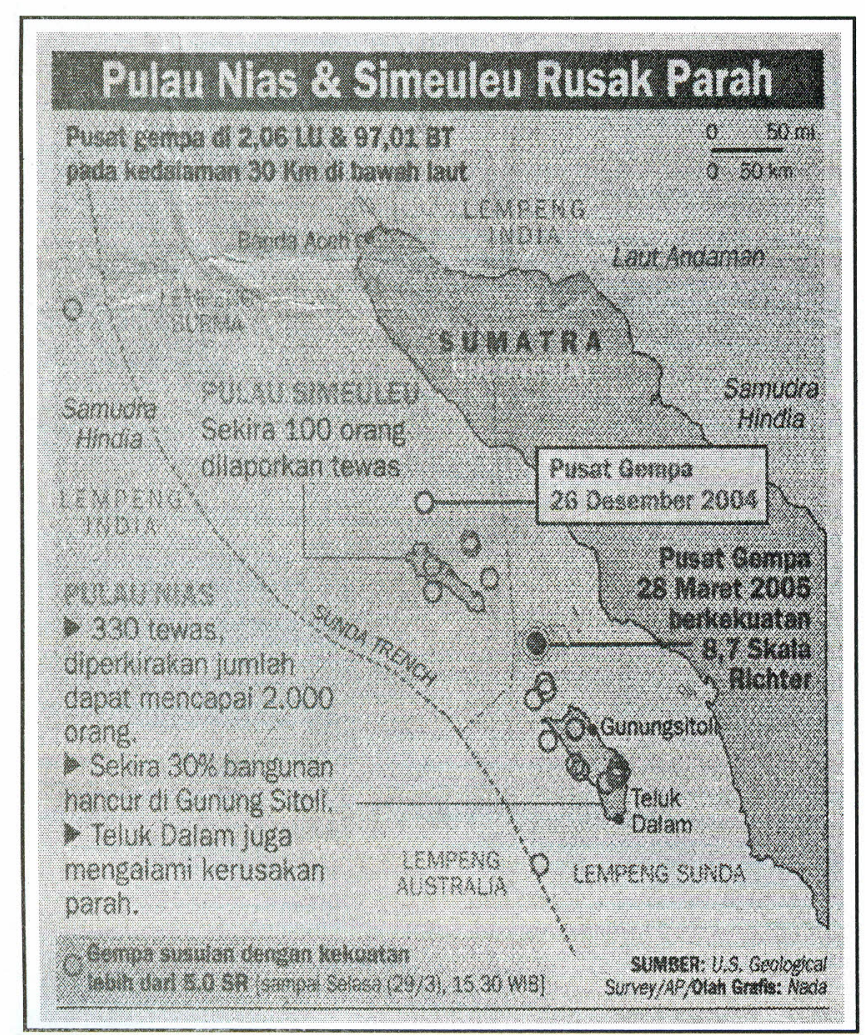

Gambar 4. Posisi P. Nias yang rawan terhadap bencana
Dengan demikian selain kualitas bahan bangunan yang memadai, juga jenis kontruksi bangunannya itu sendiri yang harus bisa tahan terhadap guncangan gempa untuk menghindari jatuhnya korban seperti akhir-akhir ini..

Untuk penyediaan bahan banguan di P. Nias, sebenarnya tidaklah terlalu sulit untuk dijangkau, karena lokasinya dekat dengan jalan atau bahkan dilewati jalan. Permasalahannya adalah karena di P. Nias sampai dengan saat ini masih kekurangan Sumberdaya Manusia yang tersedia dan sarana transfortasi menuju pulau tersebut masih kurang.

Dengan adanya data-data bahan galian bangunan tersebut paling tidak dapat mempermudah untuk pencarian atau pengadaan bahan baku untuk proses pembangunan sarana fisik di P. Nias dan sekitarnya.

\section{KESIMPULAN DAN SARAN}

\subsection{Kesimpulan}

Untuk pembangunan akibat bencana alam gempa bumi dan tsunami di P. Nias perlu adanya informasi mengenai lokasi keterdapatan dan jenis bahan bangunan serta kualitas dan kuantitasnya yang memadai. Berdasarkan hasil penyelidikan Pusat Sumber Daya Geologi, daerah ini memiliki beberapa bahan galian bangunan diantaranya;

Batugamping, potensi endapan batugamping Kabupaten Nias mempunyai luas sebaran 750 ha dengan jumlah sumber daya tereka 572.000.000 ton dan Kabupaten Nias Selatan mempunyai luas sebaran 350 ha dengan jumlah sumber daya tereka 299.000.000 ton. Batuan ini sebagian telah dimanfaatkan untuk fondasi jalan, bangunan dan jembatan.

Pasir, Sebaran pasir tersebar di 7 lokasi. luas sebaran 85 ha dengan jumlah sumber daya tereka 14.200.000 ton.

Batupasir, Potensi endapan batupasir Kabupaten Nias mempunyai luas sebaran 500 ha dengan jumlah sumber daya tereka 448.000 .000 ton. Berdasarkan hasil analisa fisik di Laboratorium memiliki kuat tekan $804,79 \quad 861,63 \mathrm{~kg} / \mathrm{cm} 2$ Batuan ini sebagian telah dimanfaatkan untuk fondasi jalan, bangunan dan jembatan.

Sirtu, Menempati di kelokan sungai-sungai dan pedataran aluvial dengan luas sebarannya \pm 25 ha serta jumlah sumber daya tereka sebesar 1.000 .000 ton.

\subsection{Saran}

Guncangan gempa yang besar di P. Nias dan sepanjang pantai barat Sumatra, telah mengakibatkan rusaknya segala fasilitas perumahan penduduk, gedung-gedung, jalan, jembatan, pertokoan dan infrastruktur lainnya. Karena itu perlu adanya perencanaan desain bangunan tahan gempa baik dengan beton maupun kayu untuk segera digalakkan dengan mengadopsi bangunan tradisional setempat. Dan untuk hal itu perlu memanfaatkan potensi sumberdaya alam dalam hal 


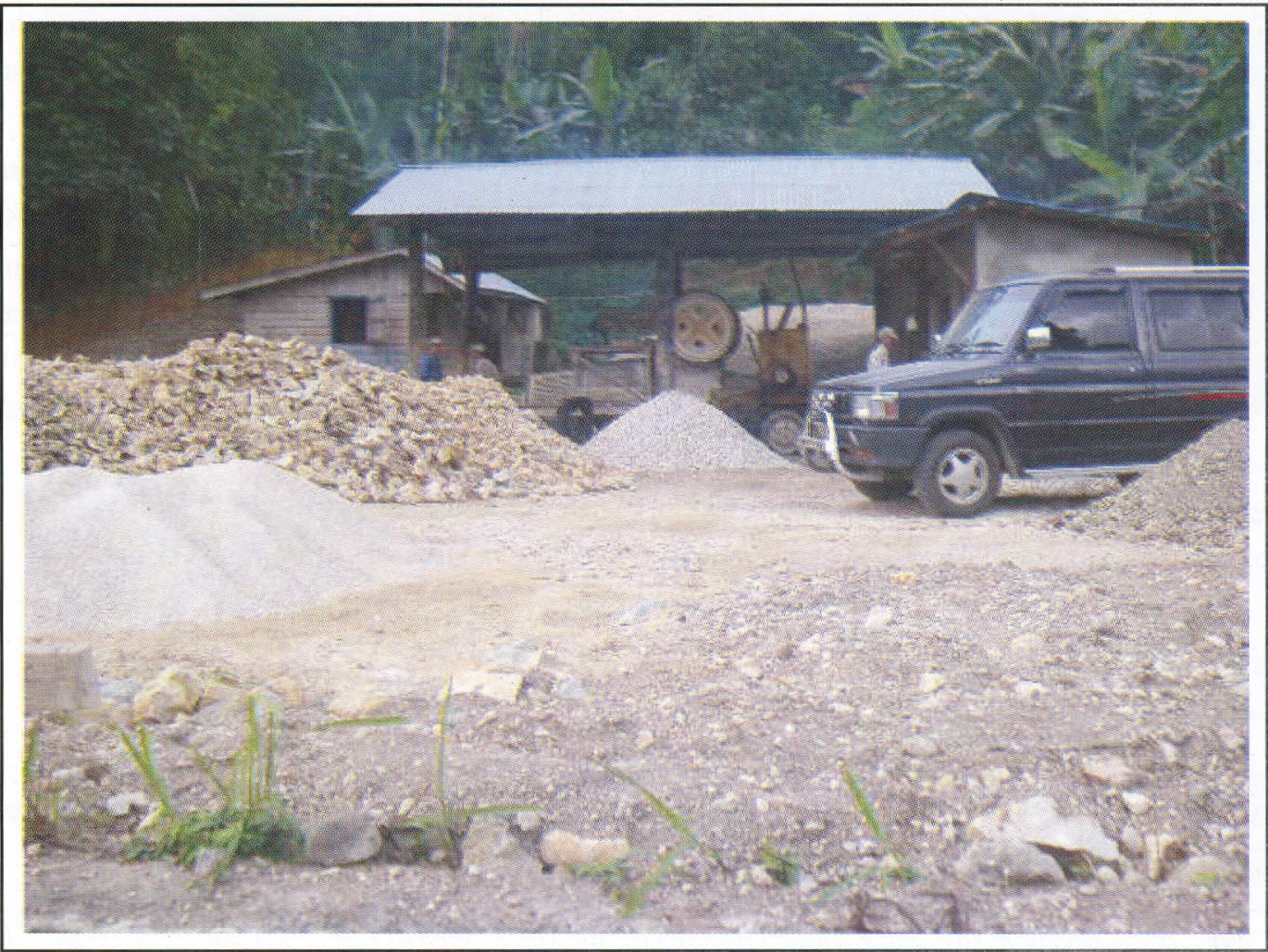

Foto 1. Tempat peggilingan batugamping menjadi kerikil (split) di lokasi sekitar Ds. Alasa dan Gunungsitoli.

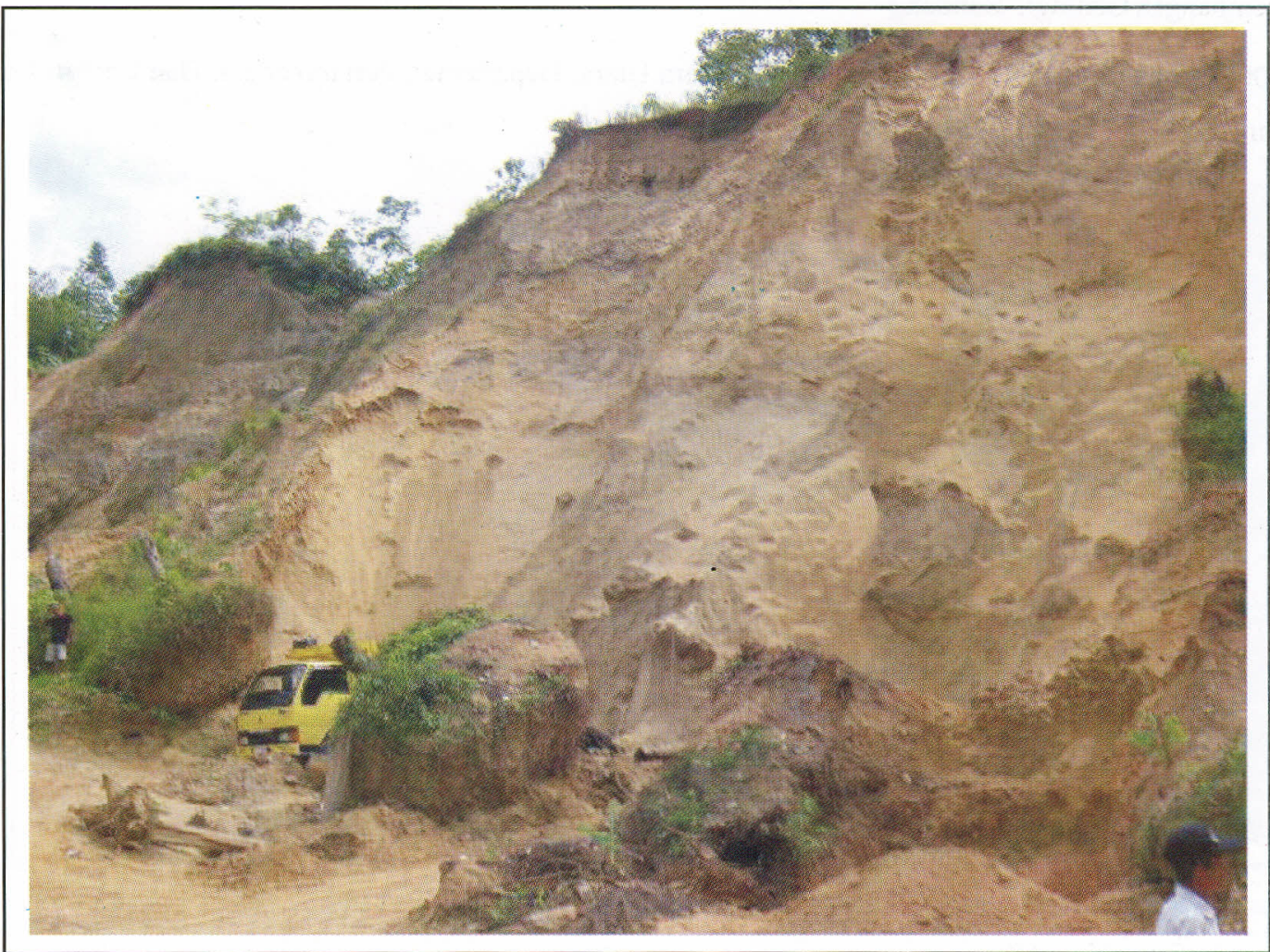

Foto 2. Lokasi penambangan pasir untuk bahan bangunan di Desa Onowombo, Kec. Teiliduho, Kab. Nias 
ini potensi bahan bangunan yang terdapat dilokasi tersebut termasuk pelepasan tiga daerah prospek, yaitu Limpoga, yang cukup potensial dengan melibatkan penduduk setempat.

Untuk mengetahui lebih lanjut tentang keberadaan bahan bangunan itu perlu diselidiki lebih rinci agar kualitas dan kuantitasnya lebih meyakinkan. Sehingga pihak yang berkepentingan akan lebih mudah mengaksesnya sekaligus memanfaatkannya.

\section{UCAPAN TERIMA KASIH}

Ucapan terimakasih yang tiada hingganya kepada:

Kepala Pusat Sumber Daya Geologi yang telah memberikan kesempatan melaksanakan penyelidikan di daerah
Kabupaten Nias dan Nias Selatan, Provinsi Sumatera Utara,

Kepala Dinas Pertambangan dan Energi Sumatera Utara yang telah membantu dalam kelancaran penyelidikan di P. Nias,

Bupati Kab. Nias dan Nias Selatan yang telah memberikan ijin untuk melaksakan penyelidikan di P. Nias,

Terakhir penulis mengucapkan terima kasih kepada Ir. Martua Raja, Ir. Herry Rodiana Eddy dan rekan lainnya di Kelompok Program Penelitian Mineral yang telah memberikan dukungan dan bantuannya sehingga makalah ini dapat terselesaikan.

Semoga segala amal baik semua pihak mendapat imbalan dari Allah SWT., amien.

\section{ACUAN}

Djamal, B. dkk, 1994, Peta Geologi Lembar Nias, Sumatera, skala 1 : 250.000, Pusat Penelitian dan Pengembangan Geologi, Bandung.

Martua Raja P., dkk., 2006, Inventarisasi dan Evaluasi Bahan Galian Non Logam di Kab. Nias dan Nias Selatan, Prov. Sumatera Utara, Pusat Sumber Daya Geologi, Bandung.

Nas, D.S. dan Supandjono, J.B. 1995, Peta Geologi Lembar Telo, Sumatera, skala 1 : 250.000, Pusat Penelitian dan Pengembangan Geologi, Bandung

Suud, A.F., 2000, Potensi Bahan Galian Industri Di Sumatera Utara, Departemen Pertambangan Dan Energi, Kanwil SUMUT, Medan. 


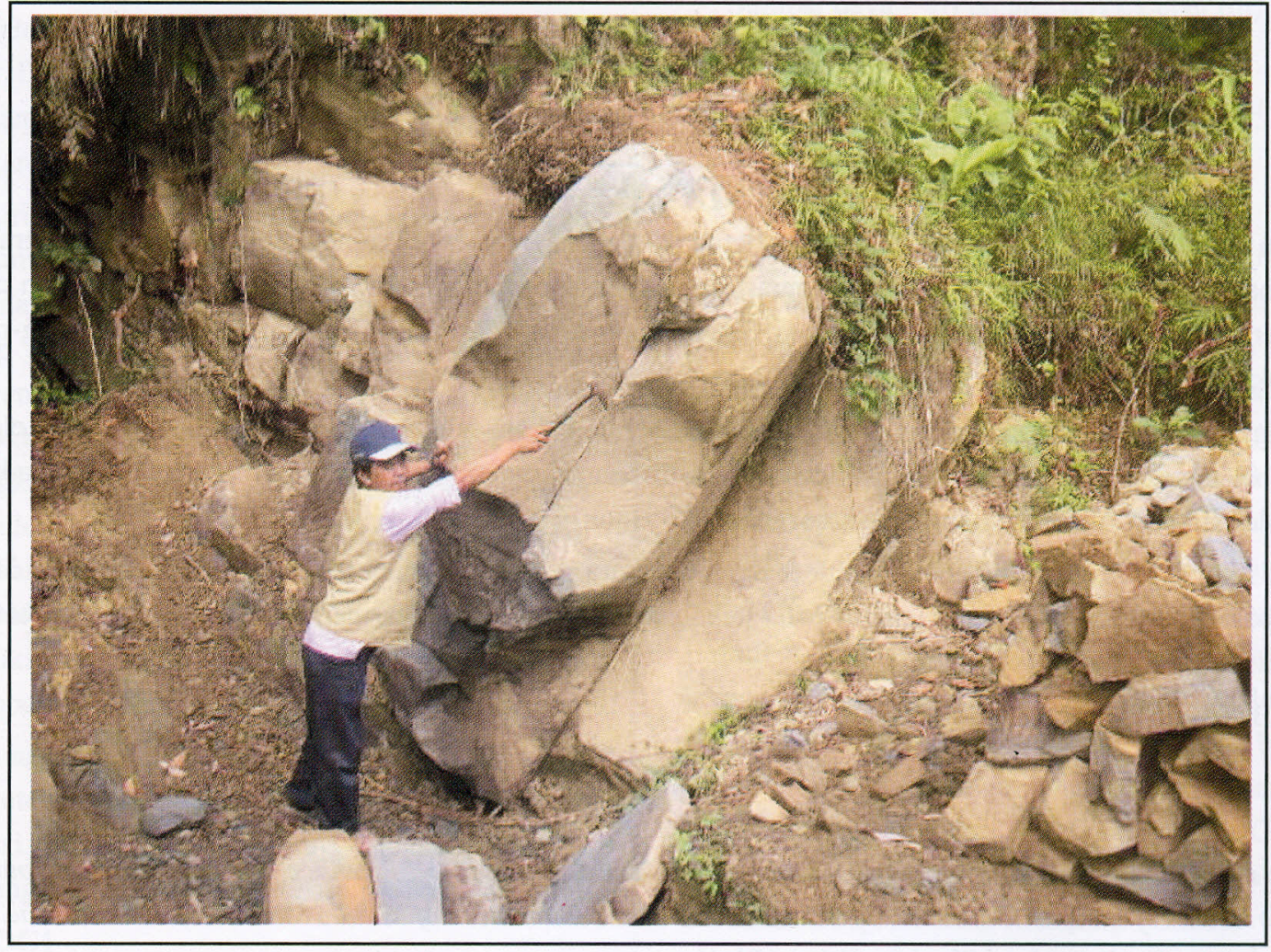

Foto 3. Singkapan batupasir yang telah ditambang rakyat di kaki Gunung Semomo di Kab. Nias Selatan

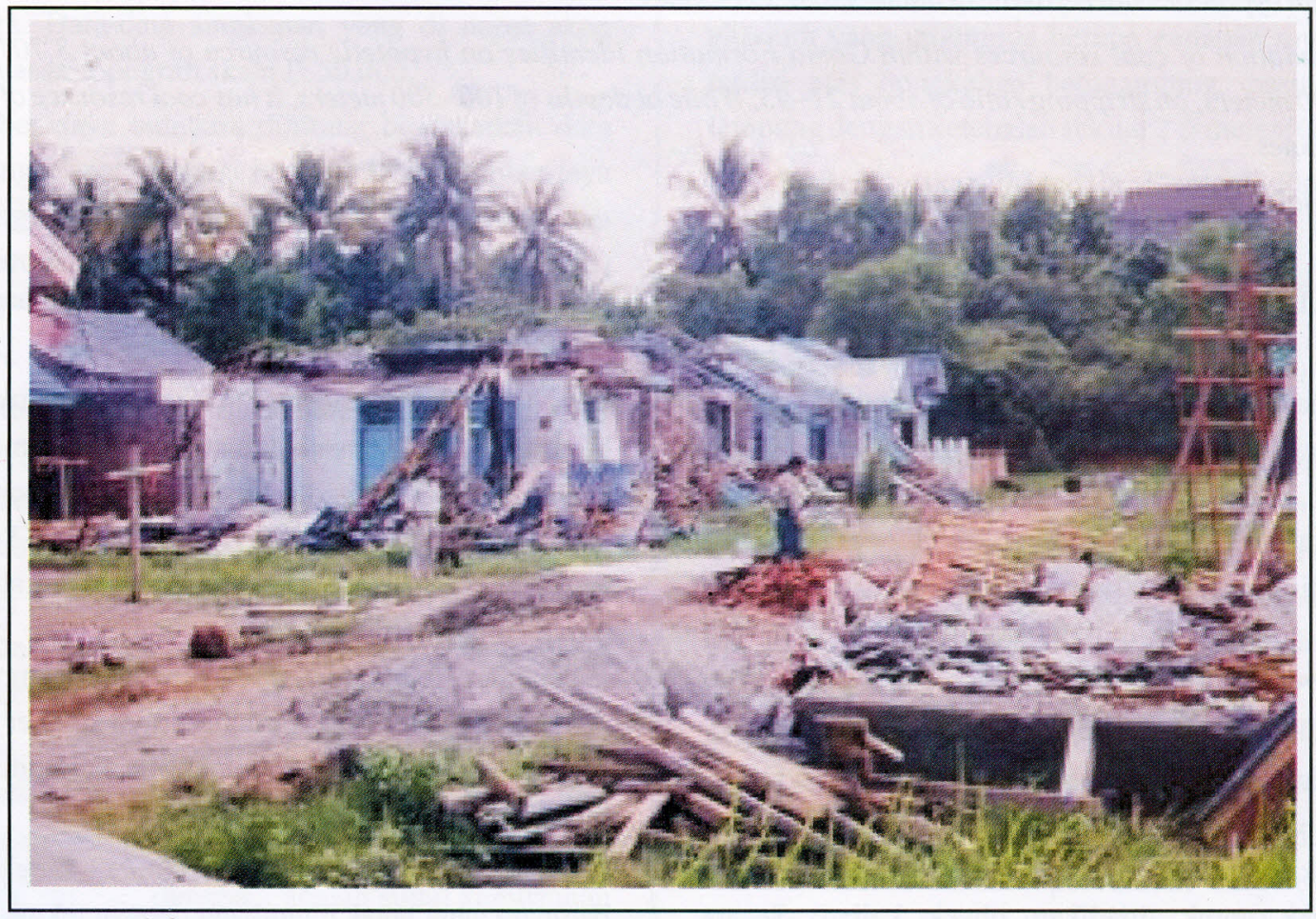

Foto 4. Lokasi perumahan yang hancur akibat guncangan gempa dan tsunami di Kota Nias, Kab. Nias, Sumut. 